\title{
MEETING OF BIOCHEMISTS IN SPAIN
}

$\mathrm{D}$ URING July 28-31 the third general meeting of Spanish biochemists was held at the University of Oviedo, organized by the Spanish Society of Biochemistry and sponsored by the Ministry of Education and the University of Oviedo. The Minister of Education, Prof. M. Lora Tamayo, himself a biochemist, was the honorary president of the meeting.

At the opening session, Dr. A. Sols and Dr. J. R. Villanueva, president and secretary, respectively, of the Spanish Society of Biochemistry, gave a short historical review of the Society including its progress as shown through the programme of these meetings and other activities. Prof. F. Grande Covian, of the University of Minnesota, spoke in representation of the scientists coming from abroad, and finally the acting rector of the University expressed his pleasure at being with the Spanish biochemists.

The meeting centred about three symposia: (a) "Enzymatic Regulation"; (b) "Microbial Motabolism"; (c) "Hormonal Metabolism". The first symposium held was under the chairmanship of Prof. S. Grisolía, of the University of Kansas, and Dr. Gertrudis de la Fuente (Madrid) described the work on the allosteric effects in hexokinases, followed by M. L. Salas, who discussed the allosteric regulation of the yeast phosphofructokinase. C. Gancedo (Madrid) described some results on the allosteric yeast fructose-1,6-diphosphatase and the regulation of gluconeogenesis. Dr. Gertrudis de Torrontegui (Madrid) described the level of pyruvate carboxylase and related enzymes in micro-organisms grown on different carbon sources. Prof. S. Grisolía presented the work carried out in collaboration with Dr. Torralba and J. Tecson at the University of Kansas on the reversible transformation of phosphoglyceromutase in diphosphoglycerate phosphatase. J. Salas (Madrid) described results of the stability and synthesis of the liver glucokinase in vitro and in vivo. Finally, A. Sillero described the induction and turnover of the glucokinase in liver. The session was followed by a general discussion, and at the end Drs. A. Sols and S. Grisolía summed up the more important points of the symposium. This session was followed by a lecture by Prof. J. Oró, University of Houston, on recent researches on hydrocarbons of biological origin found in Pre-Cambrian sediments and meteorites.

In the second symposium, under the chairmanship of Dr. C. Asensio (Madrid), Dr. D. Vázquez (Cambridge) described investigations of the effect of some antibiotics inhibiting the synthesis of proteins at tho ribosomal level. Prof. R. Parés (Barcelona) described work on amino-acid excretion by a coliform. Dr. E. Muñoz (Liège) described recent work carried out in collaboration with Drs. Ghuysen and Petit on the structure of glucopeptides of the bacterial cell wall. Dr. Concepción García Mendoza (Madrid) described the purification and chemical analysis of the eytoplasmic membrane of yeast, and finally Dr. J. R. Villanueva (Madrid) reviewed the ways in which information about yeast cell wall structure has been obtained and described some results obtained by his group at the Institute for Coll Biology. At the end of this symposium a discussion on "Unity and Variety in Microbial Biochemistry" was held, the main discussants being Drs. Losada, Mayor, Montoya, Parés, Regueiro, Sols and Villanueva. The session was followed by an address by Dr. M. Losada, director of the Institute for Cell Biology, CSIC, Madrid, who described the mechanism of the photosynthetic reduction of nitrate to ammonium.

In introducing the third symposium, Prof, F. G. Valdecasas, rector of the University of Barcelona, made some comments on the importance of the subject of hormonal metabolism. Dr. J. Gómez Acebo (Madrid) showed a collection of electron micrographs of pancreas cells during the process of insulin secretion in vitro. Dr. C. López Quijada (Madrid) reported the effects of iodoacetate and cystein on the antigenic power of insulin. Prof. C. Osorio (Granada) described the process of secretion of thyroxin in bile of monkeys. Dr. J. A. SanchezMartin (Madrid) discussed the action of thyrotrophic hormone on the intra-thyroid metabolism of the propylthiouracil. Dr. E. Herrera (Madrid) discussed the problem of experimental goitrogenesis, Dr. A. Colás (University of Oregon) described the biosynthesis of the oestriol during pregnancy, and finally Dr. A. Oriol-Bosch (Madrid) described the metabolism of tritiated progesterone by the adrenal cortex of the guinea-pig. The session ended with an address by Prof. J. L. Rodriguez Candela, director of the Marañón Institute, CSIC, Madrid, who described investigations of his group and discussed the regulation of the insulin secretion. The symposia were followed by sessions where short communications were read. In all, about forty papers were presented.

During the closing session of the meeting, Prof. F. Grande Covian gave a lecture on the role of the dietetic factors in the regulation of the plasma lipids.

Several social events were also organized, including receptions in the University and the Town Hall, and an excursion to the beautiful resorts of the Asturias coast. Nearly two hundred people attended this meeting, in cluding a notable group of Spanish research workers from abroad and many young research students. The meeting was very successful, especially in encouraging the strong development of biochemistry in Spain, which has been proceeding during the past five years. The next general meeting of the Society will be held in the University of Granada in the autumn of 1966.

The whole of the Oviedo University meeting made an important contribution to the way in which science, and in particular biochemistry, is growing in Spain. The progress has been strongly stimulated by the marked interest taken in biochemistry by some distinguished professors and research workers from the Consejo Superior de Investigaciones Cientificas and the University. Recently, increasing attention has been directed in Spain to the means of developing scientific policy and the mechanisms of scientific advice.
J. R. Villanueva

\section{LUNG TUMOURS IN ANIMALS}

$\mathrm{A}^{\mathrm{N}}$ $\mathrm{N}$ international conference on "Lung Tumours in Animals" was held at the Division of Cancer Research, University of Perugia Medical School, during June 24-29. The conference brought together many geneticists, physiologists, pathologists, virologists and biochemists, whose main interests lay in basic cancer research.

Following the opening of the conference by Prof. G. Ermini (Rettore Magnifico of Perugia University), L. C. Strong (San Diego, U.S.A.), addressing the audience as the representative of the doctors 'honoris causa' of the
University of Perugia Medical School, said that the contributions of that small select group of scientists to the human knowledge of cancer had indeed been greatand that no small part of these contributions had been made, and would presently be made, at the Conferences of the Division of Cancer Research, Perugia.

H. L. Stewart (Bethesda, U.S.A.), speaking as the representative of the National Cancer Institute, Bethesda, commented that the conference should contribute much to our knowledge of the comparative pathology of pulmon- 